\title{
Creative economy as a tool of competitiveness
}

\author{
Jana Centárová, ${ }^{1}$ \\ ${ }^{1}$ University of Economics in Bratislava, Faculty of Business Management, Department of Business Economy, Dolnozemská \\ cesta1, 85235 Bratislava, Slovak republic
}

\begin{abstract}
Creativity is a fundamental manifestation of human existence and is present in every human being in different forms. The creative economy is a natural environment for innovative ideas, development and exploitation of creative potential. Over the last two decades, it has been observed that creativity is gradually becoming a driving force for economies, and as a result the importance of creative industries is also increasing. The creative industry is increasingly becoming part of EU documents and policies. The governments of the creative countries gradually introduced the concept of the creative industry, the creative class and the creative city and their importance. The creative industry refers to those parts of the economy that create economic value on the basis of individual creative input or artistic talent. It is a sector based on the exploitation of intellectual property. The aim of this work is to briefly map the concept of creative economy and its measurement in the work of foreign and Slovak authors and describe the possible potential of this industry.
\end{abstract}

\section{Introduction}

Creativity is an opportunity to create, develop, see things from different perspectives. Every person has a certain creativity, which he can develop to a certain extent. A creative person can discover original and new solutions and make meaningful use of them. Creativity as the ability to create new solutions and problem-solving becomes a competitive advantage positively influencing economic and social development derived from talented people forming the creative class. Creative people only come up with new ideas or technologies if the right conditions are created in the form of a creative and open environment. If we want to support the development of a creative economy, it is necessary to ensure a certain degree of maturity of the economic, technological, social and cultural environment.

\section{Current state of the issue}

Many authors deal with the topic of creative economy. John Howkins and Richard Florida were among the first to address this issue. John Howkins is the author of "The Creative Economy" book, which describes the advent of a new creative workforce and creative industry. It describes the creative industry and the creative economy as a summary of four types of intellectual property:

- copyright industry,

- $\quad$ patent industry,

- trademark industry

- design industry.

They argue that the creative industry should be limited to the arts and culture without the addition of science, research or the patent industry. [1]

Richard Florida is the author of "The Rise of Creative Class" book. He sees the present as the "age of creativity". He believes that creativity represents an infinite potential, the release of which is the key to economic growth. He published research results confirming the fact that the presence of creative people living and working in the city affects the attractiveness, economic performance and competitiveness of the city. Cities are overtaking each other in attracting talent, because only those cities that are creative and supportive of interactions, knowledge exchange, generation of innovation clusters are creative. [2] 
The author Gašparík and the collective define the creative economy as an industry that deals with the connection between economy, culture, technology and asocial aspects. [3]

Sava and Badulescu are currently considered to be one of the most dynamically developing sectors of the economy. They consider the emergence of a creative economy as a shift towards a global change towards a tertiary economy, where creativity, cultural and scientific contributions by employees are its most important features. [4]

The authors of KEA European Affairs organisation have defined the creative industry on the basis of the key elements of the creative economy, based on:

- $\quad$ artistic creativity, which is the creation of new thoughts and ideas expressed in music, lyrics, works of art. In today's economy we can perceive it as creativity in science, economic creativity, technological creativity and cultural creativity.

- $\quad$ scientific creativity, which includes experiments and research to solve problems

- $\quad$ economic creativity, where creativity is a dynamic process and leads to technological, business, marketing innovation. [5]

The world organisation UNESCO has also enshrined the definition of the creative industry in its documents. It defines the cultural and creative industries as sectors of organized activity whose main purpose is the production or reproduction, promotion, distribution of goods, services and activities of a cultural, artistic or natural nature. This approach emphasizes more than just industrially produced products of human creativity, highlights the importance of the entire product chain as well as the specific functions of each sector involved in bringing these products to the public. [6 ] The UNESCO Report in 2009 sets out the characteristics of four models of the creative industry

- $\quad$ Model of the UK Department of Culture (UK DCMS)

- Symbolic text model

- Model of concentric circles,

- $\quad$ WIPO copyright model. [7]

Based on four models, UNCTAD has created its own definition of the creative industry, which we can see in more detail in the following picture 1.

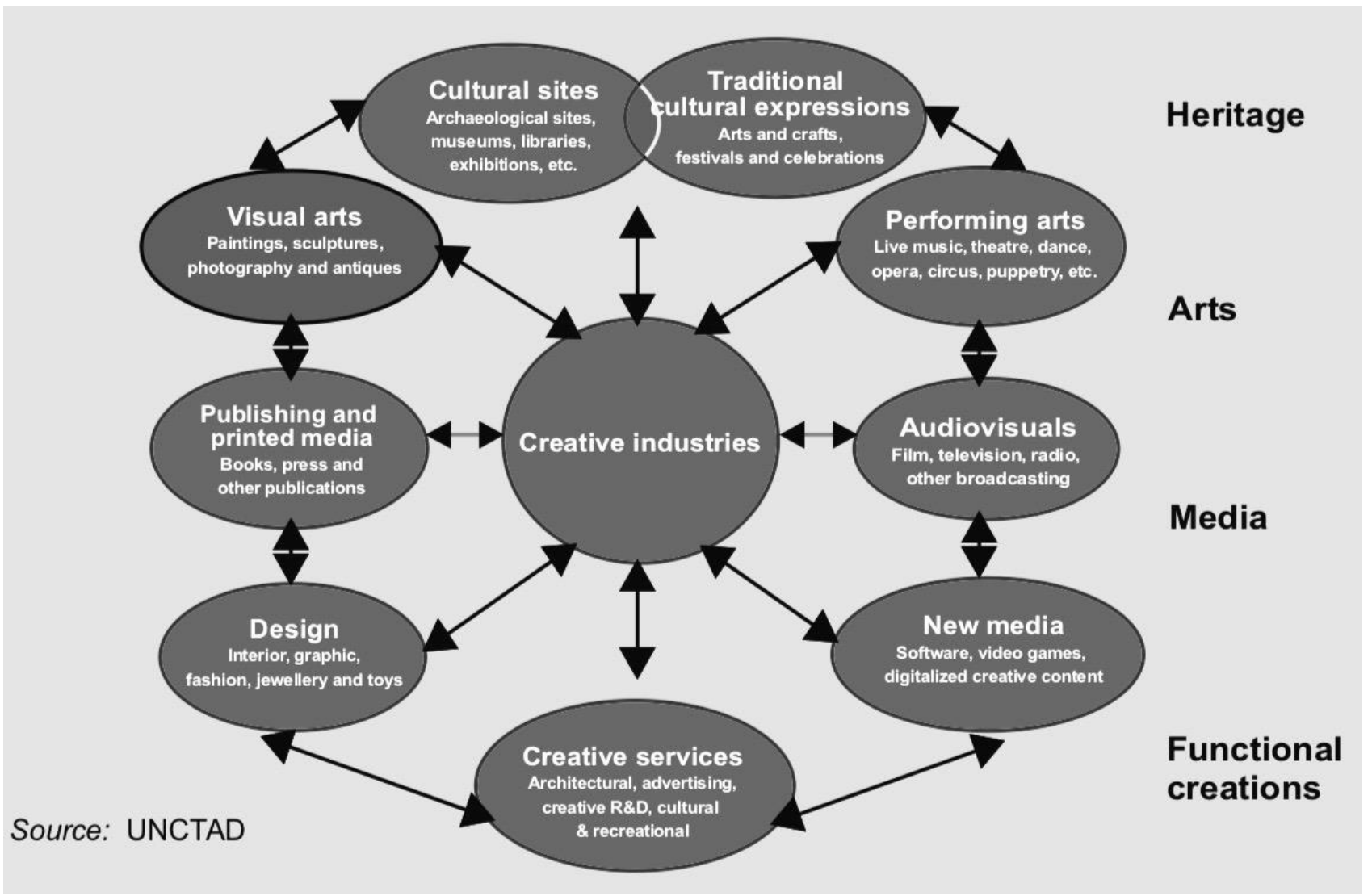

Fig. 1. Creative industry [8] 


\section{Creative industry in Slovakia}

The creative industry in Slovakia is the responsibility of the Ministry of Culture of the Slovak Republic and the Ministry of Economy of the Slovak Republic. They also work closely with the finance, education, labor and regional development sectors. In 2011, the Ministry of Culture drew up a government paper: "The Concept of Support for the Cultural and Creative Industry in the Slovak Republic", which characterizes the creative industry and was approved by the government. The characteristic states that the creative industry is to be seen as an exploitation chain that is created by creating the conditions for creative activity, and subsequently includes creative activity, production, reproduction, presentation, representation including export, storage, archiving and recovery. Furthermore, the concept states that the structure of the creative industry can be divided according to the nature of goods and services into:

- an area of arts and culture;

- an area primarily related to the use of creative activities (advertising, design, entertainment),

- the area of selling or creating access to goods or services from previous areas to consumers (hardware production, electronic communications, archiving, information services). [9]

This definition is based on definitions used in official policies of other states or international organizations, and is adapted to Slovak conditions. The starting material from 2011 was followed by the "Strategy of Creative Industry Development in the Slovak Republic" and "Action Plan 2015-2017 on the Strategy of Creative Industry Development in the Slovak Republic 2014-2020". Both materials were prepared under the auspices of the Ministry of Culture and the Ministry of Economy.

According to the creative industry strategy, they include the creation, production and distribution of products and services that use creativity and intellectual assets as primary inputs. Also, a set of knowledge-based activities, focused but not limited to the arts, potentially generating revenue from trade and intellectual property, and tangible and intangible intellectual or artistic services with creative content, economic value and market objectives. [10]

\section{The measurement of creativity-the index of creativity}

Because creative economics is constantly on the rise, there is a need of its quantification. When measuring creativity, a question comes into existence: what are we measuring, when we are measuring creativity? From psychological, sociological and economical point of view, creativity is seen as an ability. It isn't possible to measure it, however what can be measured are indicators of creativity. Looking for adequate indicators is very difficult, because uniform definitions of notions related to creative economics don't exist: what is the creative industry, cultural industry, who belongs to creative class and so on. Another problem is the valuation of creativity. The problems of creating a benchmark for measuring creative sectors consist of many factors from the practical ones to the conceptual ones. On the conceptual level, there is a problem of determining the boundaries between art, culture and industrial production. „Generally, the knowledge, that economic indicators aren't suitable for capturing every output of creative economics is accepted, on the other hand creative economics has a deep impact, not only in other sectors of economics, but generally in the society“. [11]

Most often we meet the approach of R. Florida. His approach is based on the valuation of the creative environment and the creative class. The author created the Index of creativity, based on the $3 \mathrm{~T}$, which consist of three domains, which are: technological skill, talent a tolerance. Together with his collaborators he created the Index of creativity made of

- The Index of talent with two indicators (the index of human assets and the index of creative class)

- The Index of technologies with two indicators (the index of innovation and the hi-tech index)

- The Index of tolerance with three indicators (the gay index, the index of arts and the index of migration) [12]

The approach of D. Hui and his colleagues differentiates significantly from the approach of Florida. The understanding of creative society Hui et al differentiates the most from the understanding of Florida with its classification of social assets. Hui et al created a so-called hongkong model 5C. According to their model (Outcomes of Creativity Index) the creative process continuously affects social, cultural, structural and human assets, therefore he also classified the social assets into the structure of the creative index. [13] Two of these indicators are concerned with charity contributions, the others include the indicator of generalized and institutionalized trust, reciprocity, the interest of public matters, holding modern or traditional values, contacts in the community and so on. It is possible to state, that the understanding of creativity by hongkong authors comes probably the closest to the content of the concept of krea-togenic society. [14] Graphical representation of model $5 \mathrm{C}$ is seen in the picture number 2. 


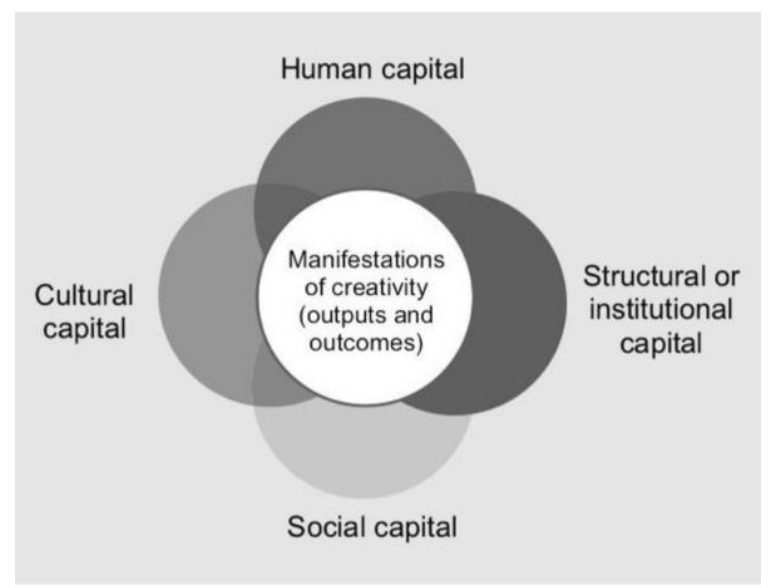

Fig. 2. Mode 5C [8]

In Slovakia, Antalová and Barta attempted to quantify the creative society. Based on the methodology of Florida and his collaborators they created their own creativity index, the so-called. Slovak-Creativity index, which is a synthetic indicator consisting of three partial indexes:

- the index of human assets,

- the index of scientific talent and

- the index of innovations. [15]

Author M. Balog and col. presented two ways of measuring the creative industry, one based on a sectoral perspective and the other on a career perspective. [16] In the Czech Republic, author J. Kloudová compiled a Czech creativity index and a situational matrix of regions of the Czech Republic, where individual regions were grouped into leaders, growth regions, delays and regions losing ground beneath their feet. [17]

\section{The creative class}

The term creative class is associated with the name of American economist and Professor Richard Florida. Florida distinguishes professions whose main function is to come up with new ideas, technologies or creative content and their bearers are representatives of the creative class, scientists, engineers, developers, architects, designers, educators, artists, musicians and many other professionals in the cultural industry - the central creative class. There is a space around the central creative class, bringing together a wider group of creative professionals working in business, finance, law, healthcare and other areas. Florida emphasizes that the prosperity of the entire locality depends on the creative class, as it boosts the growth of the entire economy of cities or regions, and therefore it is crucial to attract these people for the economic development of a particular locality. The creative class is freer, more flexible, with a higher degree of individuality than other classes. R. Florida sees the main difference between the creative class and the other working classes in what they are paid for. The working class and the class taking care of service are paid to follow a pre-prepared plan. However, the creative class is paid to be individual and independent. Richard Florida divided the creative class into two groups:

- Super-creative core is represented by the representatives of the sectors such as: scientists, engineers, education, programming, research, artists, designers, poets and the media workers. Their common feature is that they are fully involved in the creative process within their workload. The primary function of these workers is to be creative and innovative, while the production of products and services for commercial use is secondary;

- Creative professionals are classic knowledge-oriented workers, consisting of workers in the healthcare, business and finance, law and education sectors. The primary task of these employees is to solve specific problems with their knowledge and creativity. [18]

\section{The potential of the creative industry}

The Great Britain was the first European Union country to institutionalize the creative industry and include it in strategic documents at the highest political level in 1998. Howkins in his book. The creative economy. How people make Money from ideas" was the first to name a newly created creativity-based society as a creative economy. This was done based on the finding that creative workers in the US account for $41 \%$ of the workforce and account for $48 \%$ of GDP. He was the first to come up with the idea of creativity as an engine for economic growth. [12] The European Parliament affirmed the potential of the creative and cultural industry with a resolution 
on the future progress and exploitation potential of cultural industries in 2003, the second resolution on the cultural industry was published in April 2008. 2009 was declared European Year of Creativity and Innovation, reflecting the importance of innovation and promoting creativity for the development of Europe. In 2010, the Green Book on unlocking the potential of the cultural and creative industry was published. The book was intended to start a debate on the requirements to create a stimulating environment for its development and to identify opportunities for its better use to boost economic growth in Europe. In the recent decades, many researchers and economists in the US and Europe have been dealing with the creative industry and economy. The creative industry is becoming part of more and more EU documents and policies. According to the European Parliament resolution from $12^{\text {th }}$ of May 2011 on unlocking the potential of the cultural and creative industries, the EU's cultural and creative industries provide 5 million jobs and represent 2.6\% of its GDP. In 2011, the European Creative Industry Alliance was established. The creative and cultural industries are among the fastest growing industries in the world. The Paris Conference in December 2015 reported on its significant contribution to the world economy, presenting the first ever survey mapping the impact of cultural and creative industry on the world economy. According to the conference, the cultural and creative industry makes up 3\% of the world's GDP and are among the world's leading employers ( $1 \%$ of the world's active population). The development of a creative economy is linked to certain preconditions that must be met. According to Kloudová, "it is the achievement of a certain degree of maturity of the economical, technological, social and cultural environment that creates the conditions for the growth of the creative sector. The premise for the growth of the share of creative sector in the economy output is maturity and wealth of consumers, ability and education of the working force and environment, which is on a high economical and technological level, is opened to new solutions and where a good institutionalized base exists "..[17] The main feature of the global development of the creative economy is a fundamental change in the human factor in the economy, in the sense, that the production is moving increasingly to the area of innovations and ideas, to creative, original, non-traditional ways of thinking that produce new ideas and create the highest added value. The contribution of the creative and cultural industry lies in its inter-sectoral dimension with minimal territorial constraints. A complex study was brought by the company EY "Culture era - the first global map of the Creative Industry", where it analyses 11 sectors of creative and cultural industry across Europe, North America, Latin America, Asia and the Pacific, Africa and the Middle East. In every region in the world, the creative industry has an impact, as shown in the following table 1. [19]

Table 1. Creative industry in the world regions

\begin{tabular}{|c|c|c|c|}
\hline Region & $\begin{array}{c}\text { \% worldwide sales to the } \\
\text { creative industry }\end{array}$ & $\begin{array}{c}\text { \% jobs in the creative } \\
\text { industry }\end{array}$ & Note \\
\hline Europe & 32 & 26 & $\begin{array}{c}\text { strong public support, high creative } \\
\text { concentration }\end{array}$ \\
\hline $\begin{array}{c}\text { North America } \\
\text { Latin America }\end{array}$ & 28 & 16 & $\begin{array}{c}\text { Teading position in the cinematography, } \\
\text { TV industry and performing arts }\end{array}$ \\
\hline $\begin{array}{c}\text { Asia and } \\
\text { Pacific }\end{array}$ & 61 & 7 & $\begin{array}{c}\text { TV, music and dance production } \\
\text { clothing industry, cinematography growth } \\
\text { and librarianship }\end{array}$ \\
\hline $\begin{array}{c}\text { Africa and } \\
\text { Middle east }\end{array}$ & 3 & 83 & growth of film, television and music \\
production
\end{tabular}

\section{Conclusion}

The conclusions of all the studies agree that the creative sector of the economy is growing at a faster pace than most of other sectors and it ranks in a leading position among other sectors in terms of value added to the country's GDP. We can now perceive this economy as a new globalization trend in a modern society that was established at the end of the 20th century. Creativity is the basis for developing the creative economy. Creativity has been seen as a new type of competitive advantage in recent years and we need to learn how to sell our competitive advantage. Slovakia has a creative potential for the development of the creative industry and with the view of the limited 
natural mineral resources it is appropriate to focus on a creative economy, independent of exhaustible resources. The term creative industry includes several areas and at the same time defines the social requirement for a change of the perception of the concept of industry, which is now understood only in terms of pure production. In this context, industry must be seen as an exploitation chain that is being created by creating the conditions for creative activity, which then includes creative activity, production, reproduction, presentation, representation, including export, storage, archiving and recovery.

\section{References}

1. J. Howkins, The Creative Economy: How people Make Money from Ideas, London: Penguin Books, 288 (2001)

2. R. Florida, Entrepreneurship, Creativity and Regional Development. In: Hart, D. (ed): The Emergence of Entrepreneurship Policy: Governance, Start-Ups, and Growth in the U.S. Knowledge Economy. Cambridge, MA: Cambridge University Press. Higgins, L.F. "Applying principles of creati- vity management to marketing research efforts in high-technology markets”, In: Industrial Marketing Management, 28, 305-317 (2002)

3. J. Gašparík, J. Krammer, A. Václavová, GAŠPARÍK, Príležitosti kreatívnej ekonomiky, online at https://www.ia.gov.sk/data/files/NP_CSD_II/Analyzy/Stat/Prilezitosti_kreativnej_ekonomiky.\%20pdf (2017)

4. D. Sava, A. Badulescu, SAVA, The Creative Economy: Facts and Figures. In: The Annals of the University of Oradea, $\quad$ Economic Sciences, online at https://www.researchgate.net/publication/322631634_The_creative_economy_facts_and_figures (2017)

5. KEA European affairs, Promoting Investment in the $\bar{C}$ ultural and Creative (2010)

6. UNESCO, Creative Industries, online at http://www.unesco.org/new/en/santiago/culture/creative-industries/ (2017)

7. UNESCO, The 2009 UNESCO Framework for Cultural Statistics (FCS). Montreal: UNESCO Institute for Statistics. (2009)

8. Creative economy report, online at unctad.org/en/docs/ditc20082cer_en.pdf, (2008)

9. MK SR, Východiská koncepcie na podporu kultúrneho a kreatívnè ho priemyslu v Slovenskej republike. UV40861/2011, online at http://www.rokovania.sk/Rokovanie.aspx/BodRokovaniaDetail?idMaterial=20575 ( 2011 )

10. MK SR, Akčný plán na roky 2015 - 2017 k Stratégii rozvoja kreatívneho priemyslu v Slovenskej republike na $\begin{array}{lllllll}\text { roky } & 2014 & - & 2020 . & \text { Uznesenie } & \text { č. } & 11 / 2015\end{array}$ http://www.rokovania.sk/Rokovanie.aspx/BodRokovaniaDetail?idMaterial=24172 ( 2014)

11. UNCTAD, Creative Economy: A Feasible Development Option. Geneva. 'online at http://www.unctad.org/en/docs/ditc20082cer_en.pdf. (2014)

12. F. Murgaš, M. Ševčíková, Geografický prístup k meraniu kreatívneho kapátálu. 37 - 56, (2012)

13. D. Hui, N.G. Chun, P. Mok, W.K. Chin, CH. Yuen, A Study on Creativity Index. Hong Kong: Home Affairs Bureau, online ttp://http://www.hab.gov.hk/file_manager/en/documents/policy_responsibilities/arts_culture_recreation_and_spo rt/HKCI-InteriReport-printed.pdf (2005)

14. M. Kačírková, Kreativita v kontexte znalostnej spoločnosti. Bratislava: Ekonomický ústav SAV, 37. (2017)

15. M. Antalová, M. Barta, Kreatívna spoločnost' - prístupy k jej kvantifikácii v Slovenskej republike. Nová ekonomika, 157 - 165, (2013)

16. M. Balog, Možnosti rozvoja kreatívneho priemyslu na Slovensku. Bratislava: Slovenská inovačná a energetická agentúra, 66 (2017)

17. J. Kloudová, Kreatívní ekonomika a její měření, online http:/www.creative-economy.cz/dokumenty/9ekonomicky-casopis32009pdf.pdf (2012)

18. R. FLORIDA, Tinagli, I., Europe in Creative Age, online at: https://www.demos.co.uk/files/EuropeintheCreativeAge2004.pdf (2004)

19. CISAC, Nová globálna štúdia o kultúrnom a kreatívnom priemysle, online at: ://www.soza.sk/aktuality/85/cisacnova-globalna-studia-o-kulturnom-a- kreativnom-priemysle ( 2015) 